\title{
RENEWABLE ENERGY: CONCEPT, TECHNOLOGY AND USES
}

\author{
O.C. Okeke ${ }^{1^{*}}$, D. Ken-Onukuba ${ }^{2}$ and C. Enwelu ${ }^{3}$ \\ *1,2 Department of Geology, Federal University of Technology, Owerri, Nigeria \\ ${ }^{3}$ Department of Civil Engineering, Federal Polytechnic, Idah Kogi State, Nigeria.
}

*Corresponding Author: -

\begin{abstract}
: -
This paper looks into the various sources of renewable energy which includes solar, wind, geothermal, hydroelectric and biomass. Renewable energy supplies encompass a broad range of resources, and numerous technologies can be used to tap these resources. Some of these technologies include photovoltaic: solar hot water and solar thermal electric for solar energy technologies; the turbine technologies for wind energy; dry steam, flash steam, and binary cycle power plants for geothermal energy; and biochemical, thermo chemical, pyrolysis processes for biomass. The benefits associated with these energy technologies were also explored. These benefits include improved public health and environmental quality, power generation, jobs and other economic benefits; and stabilization of energy price.
\end{abstract}

Keywords: - Renewable energy, solar, wind, hydroelectric, economic benefits and improved environmental quality.

\section{(c) $(\$)$}




\subsection{INTRODUCTION}

Renewable energy is energy that comes from natural resources which are continually replenished such as sunlight, wind, biomass, water, and geothermal heat. Twidell (1986). defined renewable energy as "energy obtained from the continuous or repetitive current of energy recurring in the natural environment. Sorenson (1979) says that renewables produce energy flows which are replenished at the same rate as they are used. Approximately $16 \%$ of global final energy consumption comes from renewable sources, with $10 \%$ coming from traditional biomass, and 3.4\% from hydroelectricity. Other renewable sources accounted for another $3 \%$ and are growing very rapidly. Ibidapo et. al. (2011) explains that the word "renewable" emanated from "renew" which implies "to give new strength to something". Renewable energy thus mean: Energy that can be given new strength to.

Fossil fuels (coal, oil and natural gas) have been the main source of energy. The soaring global electricity demand, the scarcity of fossil fuel and consequently their rising price, environmental and social consequences such as climate change due to emissions of greenhouse gases particularly $\mathrm{Co}_{2}$ and air pollution has led to a global search for alternative energy sources. Renewable energy therefore constitutes a panacea of sorts, offering solutions to the problems posed by conventional energy sources.

The concept of renewable energy is that the sources are self-replenishing, inexhaustible and environmental friendly. Renewable energy technologies typically may have higher initial cost than conventional sources of energy, but their systems have long life span and low maintenance cost.

\subsection{Aspects of Renewable Energy Technology}

\section{A. Solar Energy}

Solar technology uses the sun's energy to generate energy for industrial processes, buildings, and electricity for general consumption. The sun radiates energy of about $3.5 \times 10^{14} \mathrm{KW}$ into space and only $2 \times 10{ }^{14} \mathrm{KW}$ reaches the earth (Gupta, 2000 ) - others lost by reflection, refraction and absorption. The $2 \times 10^{14} \mathrm{KW}$ reaching the earth is equivalent to burning 17 million tons of coal. This stupendous solar energy which is non-exhaustible and completely pollution free could drive civilization for life if it is properly and economically harnessed.

There are a variety of technologies that have been developed to take advantage of solar energy. These are

- Photovoltaic systems - producing electricity directly from sunlight.

- Solar Hot Water - heating water with solar energy.

- Solar Electricity - using the sun's heat to produce electricity.

- Passive Solar Heating and Day-lighting - using solar energy to heat and light buildings.

- Solar Process Space Heating and cooling- industrial and commercial uses of the sun's heat.

Some of these are discussed below.

\section{a. Photovoltaic Systems (Solar Cell)}

Solar cells, also called photovoltaic (PV) cells by scientists, convert sunlight directly into electricity. PV gets its name from the process of converting light (photons) to electricity (voltage), which is called the PV effect. The photoelectric effect was first noted by a French physicist, Edmund Bequerel, in 1839, who found that certain materials would produce small amounts of electric current when exposed to light. In 1905, Albert Einstein described the nature of light and the photoelectric effect on which photovoltaic technology is based. The first photovoltaic module was built by Bell Laboratories in 1954 when scientists at Bell Telephone discovered that silicon (an element found in sand) created an electric charge when exposed to sunlight. Soon solar cells were being used to power space satellites and smaller items like calculators and watches. Today, thousands of people power their homes and businesses with individual solar PV systems. Utility companies are also using PV technology for large power supply.

The photovoltaic cells are made of semiconducting materials. When sunlight is absorbed by these materials, the solar energy knocks electrons loose from their atoms allowing the electrons to flow through the material to produce electricity. See Fig 1.1.

Solar cells are typically combined into modules that hold about 40 cells; a number of these modules are mounted on PV arrays that can measure up to several meters on a side. These flat plate $\mathbf{P V}$ arrays can be mounted at a fixed angle facing south, or they can be mounted on a tracking device that follows the sun, allowing them to capture the most sunlight over the course of a day. Several connected PV arrays can provide enough power for a household; for large electricity utility or industrial application, hundreds of arrays can be interconnected to form a single large PV system.

Concentrator systems are designed to operate with concentrated sunlight. These cells are built into concentrating collectors that uses a lens to focus the sunlight onto the cells.

The use of concentrating collectors is limited to sunniest part of the country. They use direct beam sunlight and require sophisticated tracking devices. Flat plates on the other hand utilize the whole of the incident solar radiation.

The diagram below illustrates the operation of a basic photovoltaic cell, also called a solar cell. Solar cells are made of the same kinds of semiconductor materials, such as silicon, used in the microelectronics industry. For solar cells, a thin semiconductor wafer is specially treated to form an electric field, positive on one side and negative on the other. When light energy strikes the solar cell, electrons are knocked loose from the atoms in the semiconductor material. If electrical conductors are attached to the positive and negative sides, forming an electrical circuit, the electrons can be captured in the form of an electric current - that is, electricity. This electricity can then be used to power a load, such as a light or a tool as shown in the diagram below. 


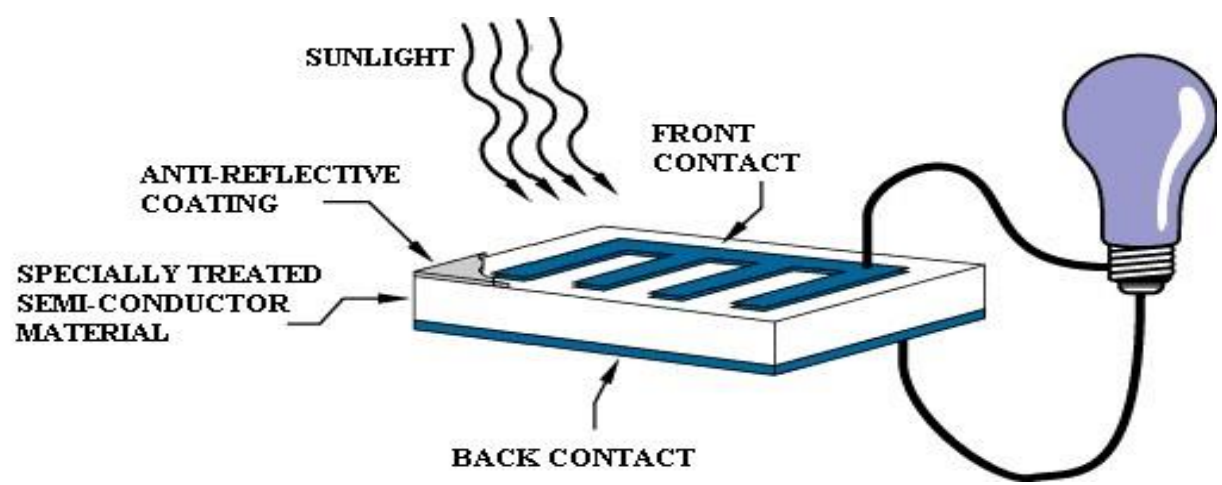

Fig 1.1 Operation of a Basic Photovoltaic Cell

Source: National Aeronautics and Space Study (NASA) science.nasa.gov/science-news/science-at-nasa/2002/solarcells/

A number of solar cells electrically connected to each other and mounted in a support structure or frame is called a photovoltaic module (Fig1.1). Modules are designed to supply electricity at a certain voltage, such as a common 12 volts system. The current produced is directly dependent on how much light strikes the module.

Multiple modules can be wired together to form an array. In general, the larger the area of a module or array, the more electricity that will be produced. Photovoltaic modules and arrays produce direct-current (dc) electricity. They can be connected in both series and parallel electrical arrangements to produce any required voltage and current combination.

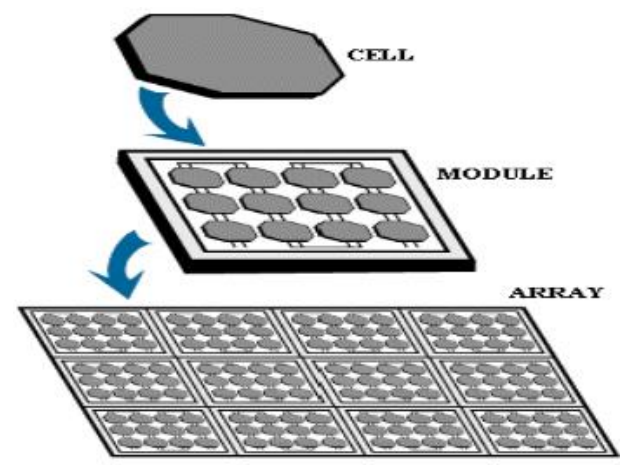

Fig.1.2Photovoltaic Cell, Module and Array Arrangement

Source: National Aeronautics and Space Study (NASA)science.nasa.gov/science-news/science-at-nasa/2002/solarcells/

Traditional solar cells are made from silicon, are usually flat-plate, and generally are the most efficient. Second-generation solar cells are called thin-film solar cells because they are made from amorphous silicon or nonsilicon materials such as cadmiumtelluride. Thin film solar cells use layers of semiconductor materials only a few micrometers thick. Because of their flexibility, thin film solar cells can double as rooftop shingles and tiles, building facades, or the glazing for skylights.

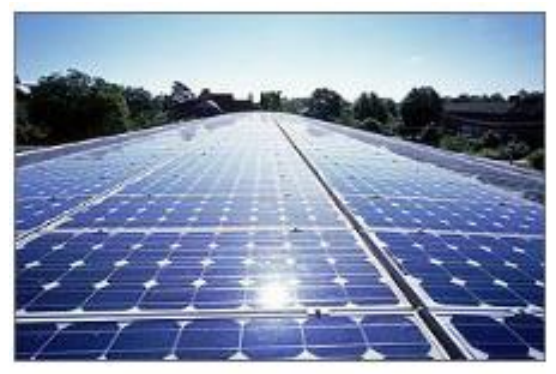

Fig 1.3 A large siticon solar array installed on the roof of a commercial building.

Source: National Aeronautics and Space Study (NASA)

science.nasa.gov/science-news/science-at-nasa/2002/solarcells/

\section{b. Solar hot water}

Solar hot water involves heating water with solar energy. Most solar water heating systems for buildings have two main parts: a solar collector and a storage tank - either water or other fluids such as antifreeze solution to be heated. The tubes are attached to an absorber plate, which is painted black to absorb the heat. As heat builds up in the collector, it heats the fluid passing through the tubes. The storage tank then holds the hot liquid, it can be just a modified water heater but it is usually larger and very well insulated. 
Solar water heating system can be either active or passive, but the most common are active systems. Active system rely on pumps to move the liquid between the collector and storage tank, while passive systems rely on gravity and the tendency for water to naturally aculeate as it is heated.

Solar water heating technology can be use in swimming pools. The pool's filter is used to pump the water through solar collector and the pool stores the hot water.

\section{c. Solar thermal-electric}

Solar thermal technologies collect and concentrate the sun's energy to create a high temperature heat source that can be converted into electricity. There are three main types of concentrating solar power systems:

- Parabolic Trough- parabolic trough systems concentrate the sun's energy through long rectangular curved ( $u$ - shaped) mirrors. The mirrors are tilted towards the sun, focusing the sun's energy onto specially coated metal pipes that run's down the centre of the trough containing a heat transfer fluid (such as synthetic oil). The oil flowing through the pipe is heated up. The hot oil is then used to boil water on a conventional steam generator to produce electricity.

- Parabolic Dish/Engine System- the parabolic dish system uses a mirrored dish (similar to a very large satellite dish). The dish shaped surface collects and concentrates the sun's heat onto a receiver which absorbs the heat and transfers it to fluid within the engine. The heat causes the fluid to expand against a piston or turbine to produce mechanical power. The mechanical power is then used to run a generator or alternator to produce electricity.

- Power Tower System- this uses a large field of mirrors to concentrate sunlight onto the top of a tower, where a receiver sits. This heats molten salt flowing through the receiver. Then, the salt's heat is used to generate electricity through a conventional steam generator. Molten salt retains heat efficiently and can be stored for days before being converted into electricity. Hence electricity can be produced on cloudy days or even several hours after sunset.

\section{d. Solar building technology}

Solar building technologies rely on the design of a building to achieve specific thermal requirement goals. Solar building technologies include

- Passive Heating and Cooling Systems - Passive heating and cooling systems use little or no mechanical assistance, relying rather on the design of the building to achieve the required thermal need. Passive space heating uses natural heat transfer process to collect, store and distribute heat. Techniques in practice today include

i) Direct Gain System: buildings for passive solar heating are designed to have large south facing windows. Since south side of a building always receives the most sunlight, materials that absorb and store the sun's heat are built into the sunlit floors and walls. The floors and walls will then heat up during the day and slowly release heat at night when the heat is needed most.

ii) Sunspaces: a sunspace (which is much like a green house) is built on the south side of a building. As sunlight passes through the glass, or other glazing, it warms the sunspace. Proper ventilation allows heat to arculate into the building.

iii) Trombe walls: a trombe wall is very thick south-facing wall, which is painted black and made of a material that absorbs a lot of heat. A pane of glass or plastic glazing, installed a few inches in front of the wall helps hold in the heat. The wall heats up slowly during the day, gives off its heat inside the building.

- Conventional passive cooling: this technique maximizes natural ventilation, incorporate well-insulated and lowemissivity building material and utilize advantageous landscaping methods (eg shade tree planting). The heat from a solar collector can also be used to cool a building. It may seem impossible to use heat to cool a building, but it makes more sense if you just think of the solar heat as an energy source just like the air condition uses electricity as energy source to create cool air.

- Active Heating and Cooling Systems: active heating systems are designed to provide large quantities of hot water or space heating for non-residential, commercial and industrial buildings utilizing a collector that receives or absorbs the incident solar energy and transfers it to a working fluid (water, oil or air) for direct use or storage. A typical system includes solar collectors that work along with a pump, a heat exchanger and one or more large storage tanks. The two main types of solar collectors used are evacuated-tube collector and a parabolic trough collector operating at high temperatures with high efficiency.

An evacuated-tube collector is a shallow box full of many glass, doubled walled tubes and reflectors to heat the fluid inside the tube. A vacuum between the two walls insulates the inner tube, holding in the heat. Parabolic troughs are long rectangular curved (u-shaped) mirrors tilted to focus sunlight on a tube which runs down the centre of the trough. This heats the fluid within the tube.

Many large buildings need ventilated air to maintain indoor air quality. In cold climates, heating this air can use large amount of energy. A solar ventilation system can pre-heat the air, saving both energy and money. This type of system uses a transpired collector, which consist of a thin black metal panel mounted on a south-facing wall to absorb the sun's heat. Air passes through the manly small holes on the panel. A space behind the perforated wall allows the air streams from the holes to mix together. The heated air is then sucked out from the top of the space onto the ventilation system. Active solar cooling technologies include solar desiccant systems that use a drying agent to absorb water vapour in building circulation air; solar heat is then used to dry or regenerate the desiccant for re-use. 
- Day-Lighting: Day-lighting is simply the use of natural sunlight to provide illumination or brighten up a building interior. This is achieved through building designs, advance optical switching materials and low-emissivity coatings for windows can further the effective use of day-lighting. Many of the passive solar heating design features also provide day lighting. To lighten up north facing rooms and upper levels, a clerestory- a row of windows near the peak of the roof - is often used along with an open floor plan inside that allows the light to bounce throughout the building.

\section{B. Wind Energy Technologies}

Wind is a form of solar energy. Winds are caused by the uneven heating of the atmosphere by the sun, the irregularities of the earth's surface and rotation of the earth.

The ability to harness the wind has existed for centuries; windmills have been used to pump water or grinding grains. Today, the windmills modern equivalent - a wind turbine - can use the wind's energy to generate electricity. The first consideration in the use of wind power is the availability of strong, reliable and persistent wind resource which must be observed and measured over time.

Wind energy was harnessed for pumping water in Nigeria as early as the 1960's. There are currently no local suppliers or manufacturers of wind energy systems in Nigeria. None of the energy research centers in Nigeria has an appreciable wind research program due to inadequate funding. There is therefore lack of capacity and experience in the country on wind power development. (Energy Commission of Nigeria, 2005). In the United States, more than 500 factories manufacture parts for wind turbines, and the amount of domestically manufactured equipment used in wind turbines has grown dramatically in recent years: from 35 percent in 2006 to 70 percent in 2011 (Wiser et. al., 2012).

\section{a. Components of a wind turbine}

Wind technologies convert the energy of moving air masses for mechanical energy needs (e.g. milling or water pumping) or converted to electric power by the use of wind turbines. Modern wind turbines fall into two basic groups based on the axis of blade rotation; the horizontal - axis and the vertical axis-turbines. Most large modern wind turbines are horizontal axis turbines horizontal turbine components include

- Blade or rotor.

- A driven train, usually including a gear box and a generator.

- A tower that supports the rotor and drive train; and

- Other equipments - controls, electrical cables, ground support equipment, and inter connection equipment.

Wind turbines, like wind mills, are mounted on a tower to capture the most energy. At 100 feet (30 meters) or more above ground, they can take advantage of faster and less turbulent wind. Turbines catch the wind's energy with their propellerlike blades. Usually, two or three blades are mounted on a shaft to form a rotor.

A blade acts much like an air plane wing. When wind blows, a pocket of low-pressure air forms on the downwind side of the blade. The low-pressure air pocket then pulls the blade towards it, causing the rotor to turn. This is called a lift. The force of the lift is actually much stronger than the wind's force against the front side of the blade, which is called drag. The combination of lift and drag causes the rotor to spin like a propeller, and the turning shaft spins a generator to make electricity. The force of the wind causes the rotor to spin like a propeller, and the turning shaft spins a generator to make electricity.

Wind turbines can be used as stand-alone application for water pumping, agriculture, homes, ranchers etc. Wind turbines can also be connected to utility power grid. For bulk electricity, a large numbers of wind turbines are usually built chose together to form a single wind power plant also known as a wind farm. Electricity from these turbines is fed into a utility grid and distributed to customers, just as with conventional power plant.

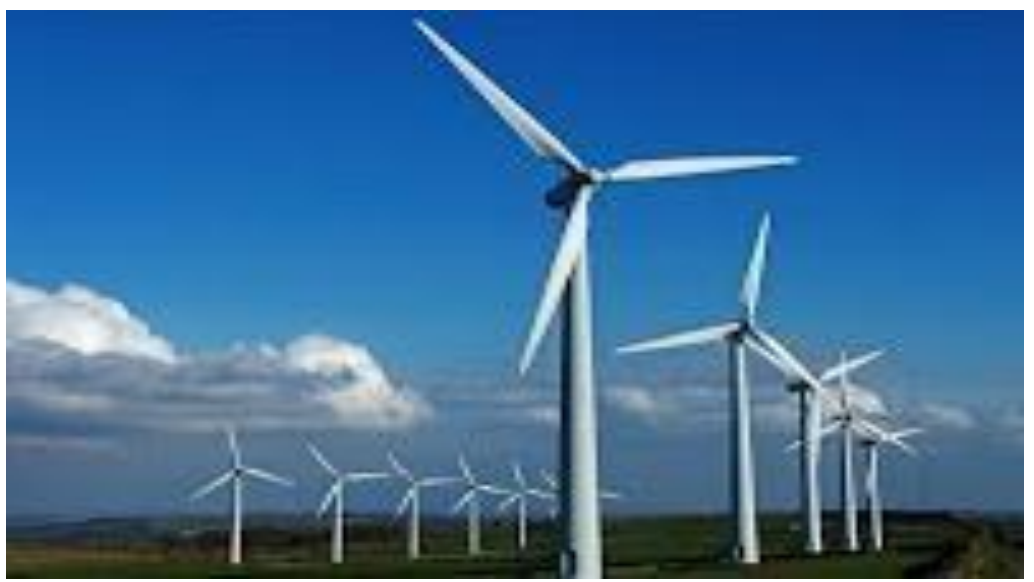

Fig 2.1 Wind Turbine

Source: (Green Cyclopedia, www.greencyclopedia.com).

\section{Geothermal Energy Technologies}

Geothermal energy is the heat from the earth. The temperature of the earth increases towards its center. It's a clean and sustainable source of energy. The potential size of the resources is very large although conversion technologies for fully 
accessing the estimated 100 million quads of available worldwide resources are yet to be proven. Resources of geothermal energy include the heat retained on shallow ground, hot water and rock found a few miles beneath the earth's surface, and extremely high temperature molten rock called magma located deep in the earth. Geothermal energy technologies includes

- Producing heat directly from hot water within the earth - geothermal direct use.

- Geothermal heat pumps

- Generating electricity from the earth's heat - geothermal electricity production.

\section{a. Geothermal direct use}

Geothermal direct use dates back thousands of years, when people began using hot springs for bathing, cooking etc. Today, there are now more sophisticated ways of using these geothermal resources.

In modern direct use system, a well is drilled into a geothermal reservoir to provide a steady stream of hot water, the water is brought up through the well, and a mechanical system-piping, a heat exchanger and controls delivers the heat directly for its intended use. A disposal system then either injects the cooled water underground or disposes of it on the surface.

Direct use applications include heating buildings, growing plants in green houses, drying crops, heating water at fish farms, pasteurizing milk etc

\section{b. Geothermal heat pump (GHP)}

Geothermal heat pumps take advantage of shallow ground temperatures to heat and cool buildings. Geothermal heat pump system consists of basically three parts; the ground heat exchange, the heat pump unit, and the air delivery system (ductwork). The heat exchanger is basically a system of pipes called a loop, which is buried in the shallow ground near the building. A fluid (usually water or a mixture of water and antifreeze) circulates through the pipes to absorb or relinquish heat within the ground. The ground temperature is warmer than the air above it in winter and cooler than the air in the summer.

In the winter, the heat pump removes heat from the heat exchanger and pumps it into the indoor air delivery system. In the summer the process is reversed and the heat pump moves heat from the indoor air into the heat exchanger. Geothermal heating pumps are reversible; hence they provide space heating on the winter and space cooling in the summer as well as supplement domestic hot water needs year round. All areas of the United States have nearly constant shallow-ground temperatures, which are suitable for geothermal heat pumps. Hence, a lot of these systems have been installed in the United States.

\section{Hydropower}

Hydropower or water power is power derived from the energy of falling water and running water, which may be harnessed for useful purpose. Since ancient times, hydropower has been used for irrigation and operation of various mechanical devices such as water mills, saw mills, textile mills etc

The modern era of hydropower development began in 1870 when the first hydroelectric power plant was installed in Cragside, England. The commercial use of hydropower started in 1880 in Grand Rapids, Michigan, where a dynamo driven by a water turbine was used to provide theatre and store front lighting (IPCC, 2011).These early hydropower plants had small capacities by today's standards but pioneered the development of the modern hydropower industry.

Hydropower technologies use flowing water to create energy that can be captured and turned into electricity. Both large and smallscale power producers can use hydropower technologies to produce electricity. The amount of available energy in moving water is determined by its flow or fall. Swiftly flowing water on a big river, like the Columbia River that forms the border between Oregon and Washington, carries a great deal of energy in its flow. Water descending rapidly from a very high point, like Niagara Falls in New York, also has lot of energy in its flow. Hydropower technology is currently mature and widely available. Almost $15 \%$ of the world's electrical energy comes from hydroelectric facilities operating in over 80 countries (Moreira, et. al., 1993).

Development of a hydropower site requires analysis of flow records, sometimes spanning decades, to access the reliable annual energy supply. Hydropower is the most matured, reliable and cost effective renewable power generation technology available (Brown, et. al, 2011). Hydropower schemes often have significant flexibility in their design and can be designed to meet base-load demand with relatively high capacity factors, or have higher installed capacities and a lower capacity factor, but meet a much larger share of peak demand. Hydropower is the largest renewable energy source, and it produces about $16 \%$ of the world's electricity.

Hydropower schemes range in size from just a few watts for Picohydro to several giga watts or more for large scale projects. Larger projects will usually contain a number of turbines but smaller projects may rely on just one turbine. The two largest hydropower projects in the world are the 14GW Itapu project in Brazil and the three Georges projects in China with 22.4GW (IPCC 2011)

\section{a. Components of a hydropower}

The main components of a conventional hydropower plant are shown in the diagram below. The components include: Dam: Most hydropower plants rely on a dam that holds back water, creating a large water reservoir that can be used as storage. There may also be a de-silter to cope with sediment build-up behind the dam.

Intake, Penstock and Surge chambers: Gates on the dam opens and gravity conducts the water through the penstock (a cavity or pipeline) to the turbine. There is sometimes a head race before the penstock. A surge chamber or tank is used to reduce surges on water pressure that could potentially damage or lead to increased stress on the turbine. 
Turbine: The water strikes the turbine blades and turns the turbine which is attached to a generator by a shaft. There is a range of configuration possible with the generator above or next to the turbine. The most common type of turbine for hydropower plant in use today is the Francis turbine, which allows a side-by-side configuration with the generator.

Generator: As the turbine blade turns, the rotor inside the generator also turns and electric current is produced as magnets rotate inside the fixed-coil generator to produce alternating current (AC)

Transformer: The transformer inside the power house takes the AC voltage and converts it into higher-voltage current for more efficient (lower losses) long-distance transport.

Transmission lines: Send the electricity generated to a gridconnection point, or to a large industrial consumer directly, where the electricity is converted back to a lower-voltage current and fed into the distribution network.

Outflow: Finally, the used water is carried out through pipelines, called tail races, and re-enters the river downstream. The outflow systems may also include "spill ways" which allow the water to bypass the generation system and be "spilled" in times of flood or very high inflows and reservoir levels.

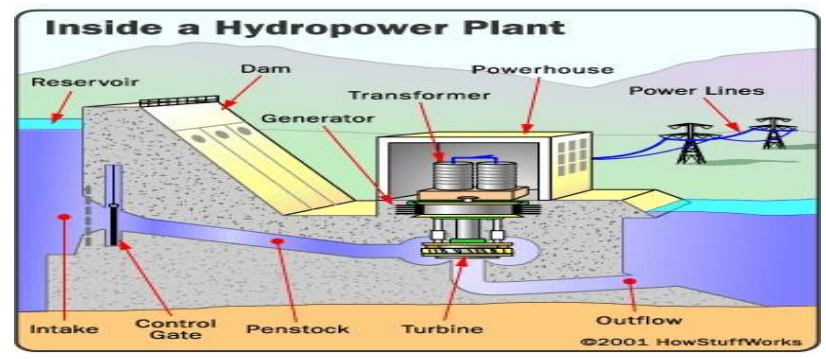

Fig.4.1 Components of a Hydropower Plant

Source: http://science.howstuffworks.com/environmental/energy/hydropowerplant

\section{b. Large-Scale Hydropower}

Largescale hydropower plants are generally developed to produce electricity for government or electric utility projects (over 15MW). Most large scale hydropower projects use a dam and a reservoir to retain water from a river. When the stored water is released, it passes through and rotates turbines, which spins generators to produce electricity. Water stored in reservoirs can be accessed quickly for use during times when the demand for electricity is high.

Dammed hydropower projects can also be built as power storage facilities. During periods of peak electricity dammed, these facilities operate much like a traditional hydropower plant - water released from the upper reservoir passes through turbines, which spins generators to produce electricity. However, during periods of low electricity use, electricity from the grid is used to spin the turbine backwards, which causes the turbine to pump water from a river or lower reservoir to an upper reservoir, where the water can be stored until the demand for electricity is high again.

\section{c. Small-Scale Hydropower (Micro Hydropower)}

Micro hydropower systems are small hydroelectric power systems of less than 100KW used to produce electricity for farms, ranches, homes and villages.

The run-of-the river technology is most often used for micro hydropower systems. The run- of- the river system do not require large storage reservoirs. For run- of- the river micro hydropower systems, a portion of a river is diverted to a water conveyance channel, pipeline, or pressurized pipeline (called a penstock) that delivers it to a turbine or waterwheel. The moving water rotates the wheels or turbine, which spins a shaft. The motion of the shaft can be used for mechanical processes such as pumping water, or it can be used to power an alternator or generator to generate electricity. Other components include a regulator, which controls the generator and wiring which delivers electricity.

However, there is no agreed classification of "small" and "large" hydro. What constitutes "small" and "large" hydro varies from country to country. (IPCC, 2011).

\section{E. Biomas Energy}

Biomass energy or bio energy refers to energy derived from the conversion of organic and waste materials. According to Karekezi, et. al., 1997. biomass energy or bioenergy refers to energy derived from the conversion of biomass into liquid or gaseous fuel. Bio energy has been used for thousands of years, ever since people started burning wood to cook food or to keep warm. And today, wood is still the largest biomass energy source.

Biomass is by far the most complex of the renewable energy resources and presents the most complex difficult assessment problems. The complexity is due to the multiple sources of biomass including energy crops (e.g. trees, corn, sugarcane, microalgae); standing crops (mostly forests) agricultural waste(field, mill or factory), animal dung, organic components of municipal waste, and to the many energy conversion processes that are possible, including direct combustion, gasification, liquefaction, and biochemical processing. These energy crops, such as fast growing trees, grasses, wood, charcoal, animal dung, agricultural residue, sawmill etc are called biomass feedstock (Fig 5.1)

The first step after determining end-use needs biomass feed stock is to take inventory sources of biomass and their availability (Hall, 1993). Once the resources and availability are identified, harvesting rates, transportation, storage and conversion issues must be considered. The process used depends on the type of biomass and its intended end-use.

Perhaps one of the most promising innovations in recent years is clean energy derived from algae. The slimy green stuff that collects on surface water is filled with fuel potential: Some kinds of algae are comprised of more than $50 \%$ oil and 
contribute zero emissions to greenhouse gases. According to the World Watch Institute, an average acre of algae grown today for pharmaceutical industries can produce 5,000 gallons (19,000 liters) of biodiesel each year. In contrast, an average acre of corn produces 420 gallons (1,600 liters) of ethanol per year, and an acre of soybeans yields just 70 gallons (265 liters) of biodiesel per year (Green Cyclopedia, www.greencyclopedia.com.).

There are three major biomass energy technology applications.

- Biofuels - converting biomass into liquid fuels for transportation.

- Biopower - burning biomass directly, or converting it into gaseous fuel or oil, to generate electricity.

- Bioproducts - converting biomass into chemicals for making products that typically are made from petroleum.

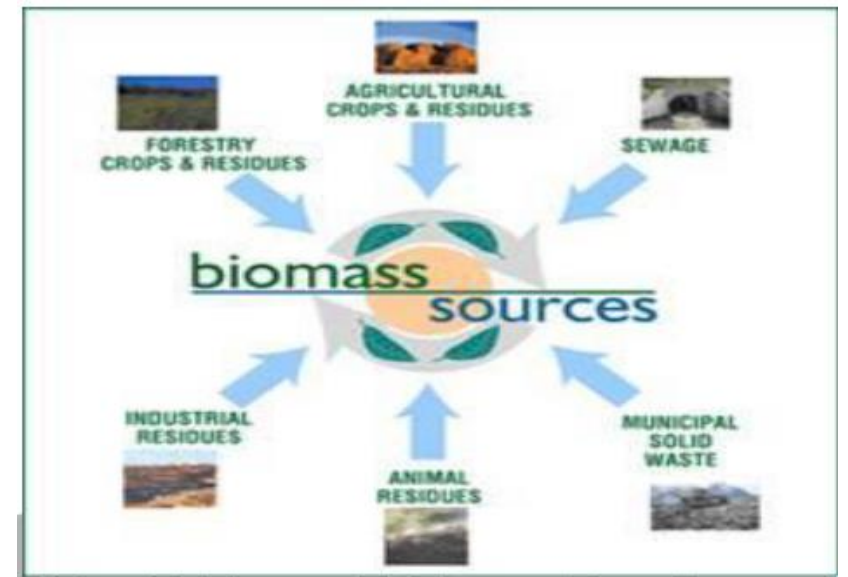

Fig.5.1Sourcesof Biomasshttp://www.oregon.gov/ENERGY/renew/biomass/Pages/biomasshome.aspx

\section{a. Biofuels}

Unlike other renewable energy resources, biomass can be converted directly into liquid fuels produced from biomass biofuels. Biofuels are liquid or gaseous fuels produced from biomass for transportation (cars, trucks, buses, airplanes, trains), but some are used as fuel to produce electricity. The two most common types of bio-fuels are ethanol and biodiesel.

\section{- ETHANOL:}

Ethanol is a renewable fuel made from various plant materials (biomass). Ethanol is an alcohol, it contains the same chemical compound $(\mathrm{C} 2 \mathrm{H} 5 \mathrm{OH})$ found in alcoholic beverages such as beer and wine. It is made by fermentation of biomass high on carbohydrates such as starch in corn grains, sugars and cellulose feedstock (such as grass, wood, crop residue). Ethanol is most commonly used as an additive to petroleum-based fuels to reduce toxic emissions and increase octane. Octane helps to prevent engine knocking. Today, roughly half of the gasoline sold in the United States includes 5\%-10\% ethanol. Ethanol is blended with gasoline in various amounts for use in vehicles. Low level blends, up to E10 ( $10 \%$ ethanol, $90 \%$ gasoline) can be used legally in any gasoline-powered vehicle E85 (85\% ethanol, 15\% gasoline) can be used in flexible vehicles which are designed to tolerate the fuel's high ethanol content. E85 cannot be used legally in standard gasoline-powered vehicles. Fueling vehicles with pure ethanol (E100) creates problem during cold weather operation.

- BIODIESEL: Biodiesel is produced through a process that combines organically derived oils (vegetable oil, animal fat, or recycled cooking greases) with alcohol (ethanol and methanol) in the presence of a catalyst to form ethyl or methyl esters. The biomass-derived ethyl or methyl esters can be blended with conventional diesel fuel or used as neat fuel (100\% biodiesel). Biodiesels can be legally blended with petroleum diesel in any percentage. The percentages are designated as B20 for blend containing 20\% biodiesel and 80\% petroleum diesel. B100 for 100\% biodiesel, and so forth. Biodiesel reduces vehicle emissions; it is non-toxic and biodegradable.

\section{b. Biofuel Conversion Processes}

The conversion of biomass solids into liquid or gaseous bio-fuels is a complex process. Today, the most common conversion processes are biochemical and thermo chemical based. However researchers are also exploring photo biological conversion process.

- Biochemical Conversion Processes - in biochemical conversion processes, enzymes and micro-organisms are used as biocatalyst to convert biomass into desirable products. Cellulose and hemicellulose enzymes break down the carbohydrate fractions of biomass to five-and-six carbon sugars in a process known as hydrolysis. Yeast and bacteria then ferment the sugars into products such as ethanol.

- Thermochemical Conversion Process - heat energy and chemical catalysts can be used to break down biomass into intermediate compound or products. In gasification, biomass is heated in an oxygen-starved environment to produce a gas composed mainly of hydrogen and carbon monoxide.

- Pyrolysis - in pyrolysis biomass is exposed to high temperature in the absence of air, causing it to decompose. Solvents, acids, and bases can be used to fractionate biomass into an array of products including sugars, cellulose fiber and lignin. 
- Photochemical Conversion Processes - Photochemical conversion process use the natural photosynthetic activity of organisms to produce bio-fuels directly from sunlight. For example, the photosynthetic activities of bacteria and green algae have been used to produce hydrogen from water and sunlight.

\section{c.Biopower}

Bio-power is the production of electricity or heat from biomass resources. With 10 giga watts of installed capacity, biopower technologies are proven options in the United States today. Biomass energy are emerging as an economically viable option for satisfying power needs in both industrialized and developing countries (ongrid and off-grid. Where the resource conditions are favorable, power systems based on feedstocks can produce electricity at costs that are comparable with conventional fossil-based alternatives (Carpentieri, et. al., 1993; Russell, et. al., 1992; and Periack, et. al., 1991).

Bio-power technologies include:

- Direct Combustion - Most electricity generated from biomass is produced by direct combustion using conventional boilers. These boilers primarily burn bio-energy feedstock (e.g. waste wood products from agricultural and woodprocessing industries) to produce steam. This is usually captured by a turbine, and a generator then converts it into electricity. In some industries, the steam from the power plant is also used for manufacturing processes or to heat buildings. For instance, wood waste is often used to produce both electricity and steam at paper mills. Most of the bio-power plants in the world use direct-fired system.

- Co-Firing - Co-firing involves using bio energy feedstock as supplementary energy source in high efficiency boilers. Many coal-fired plants can use co-firing to significantly reduce emissions, especially sulphur dioxide. A portion of the petroleum-based fuel in high-efficiency coal-fired boilers is replaced with biomass. Co-firing has been successfully demonstrated in most boiler technologies, including pulverized coal, cyclone, fluidized bed, and spreader stroker units.

- Anaerobic Digestion - anaerobic digestion is a common technology in today's agriculture, and brewing industries. It uses bacteria to break down waste organic materials into methane and other gases, which can be used to produce electricity or heat. The same types of bacteria used to produce natural gas also produce methane today. Anaerobic bacteria break down or "digest" organic materials in the absence of oxygen and produces biogas as a waste product. Methane can be used as an energy source in many ways. Most facilities burn it in a boiler to produce steam for electricity generation or for industrial processes. Two new ways include the use of micro-turbines and fuel cells. Microturbines have outputs of $25-500 \mathrm{KW}$, about the size of a refrigerator and can be used where there is space limitation for power production. Methane can also be used as the "fuel" in a fuel cell. Fuel cells work much like batteries but never need recharging, producing electricity as long as there is fuel.

- Pyrolysis - In addition to gas, liquid fuels can be produced from biomass through a process called pyrolysis. Pyrolysis occurs when biomass is heated in the absence of oxygen. The biomass then turns into a liquid called pyrolysis oil which can be burned like petroleum to generate electricity.

\section{d. Bio-based Products}

Almost all of the products we currently make from fossil fuel can be made from biomass. These products are not only made from renewable sources, but also require less energy to produce than petroleum based products. Researchers have discovered that the process for making bio-fuels - releasing the sugars that make up starch and cellulose in plants -also can be used to make antifreeze, plastics, glues, artificial sweeteners, and gel for toothpaste.

When biomass is heated with a small amount of oxygen, carbon monoxide and hydrogen (biosynthetic gas) are produced in abundance. Biosynthesis gas can be used to make plastics and acids, which can be used to make photographic films, textiles and synthetic fabrics. Phenol can be extracted from pyrolysis oil, and it is used to make wood adhesive, molded plastics, and foam insulation.

In future, there may be bio-refineries like petroleum refineries producing not only bio-fuels but also a variety of bioproducts. There are several biomass feedstocks that are currently being used/considered. The chart below outlines the technology used, the type of conversion processes for each feedstock and the end product. 
Table 1 Biomass Feedstock Technology/Conversion Processes

\begin{tabular}{|c|c|c|c|}
\hline Technology & $\begin{array}{l}\text { Conversion } \\
\text { Process Type }\end{array}$ & $\begin{array}{l}\text { Major Blomass } \\
\text { Foedstock }\end{array}$ & $\begin{array}{l}\text { Energy or Fuel } \\
\text { Produced }\end{array}$ \\
\hline $\begin{array}{l}\text { Direct } \\
\text { Combustion }\end{array}$ & Thermochemical & $\begin{array}{l}\text { Wood, agricultural waste, } \\
\text { municipal solid wasto. } \\
\text { residential fuels }\end{array}$ & $\begin{array}{l}\text { heat } \\
\text { steam } \\
\text { electricity }\end{array}$ \\
\hline Gasification & Thermochemical & $\begin{array}{l}\text { Wood, agricultural waste, } \\
\text { municipal solid waste }\end{array}$ & $\begin{array}{l}\text { low or medium-Btu } \\
\text { producer gas }\end{array}$ \\
\hline Pyrolysis & Thermochemical & $\begin{array}{l}\text { Wood, agricultural waste, } \\
\text { municipal solid waste }\end{array}$ & $\begin{array}{l}\text { synthetic fuel oil } \\
\text { (biocrude) } \\
\text { charooal }\end{array}$ \\
\hline $\begin{array}{l}\text { Anaerobic: } \\
\text { Digestion }\end{array}$ & $\begin{array}{l}\text { Biochemical } \\
\text { (anaerobic) }\end{array}$ & $\begin{array}{l}\text { animal manure, } \\
\text { agricuitural waste, } \\
\text { lendillts, wastewater }\end{array}$ & $\begin{array}{l}\text { medium Btu gas } \\
\text { (methane) }\end{array}$ \\
\hline $\begin{array}{l}\text { Ethanol } \\
\text { Production }\end{array}$ & $\begin{array}{l}\text { Biochernical } \\
\text { (anrobic) }\end{array}$ & $\begin{array}{l}\text { sugar or starch crops, } \\
\text { wood waste, } \\
\text { pulp sludge, grass straw }\end{array}$ & ethanol \\
\hline $\begin{array}{l}\text { Biodiessel } \\
\text { Production }\end{array}$ & Chemical & $\begin{array}{l}\text { Rapeseed, } \\
\text { soy beans, } \\
\text { waste vegetable oll, } \\
\text { animal fats }\end{array}$ & biodiesel \\
\hline $\begin{array}{l}\text { Methanol } \\
\text { Production }\end{array}$ & Thermochemical & $\begin{array}{l}\text { Wood, agricultural waste. } \\
\text { municipal solid waste }\end{array}$ & methanol \\
\hline
\end{tabular}

Source: http://www.oregon.gov/ENERGY/renew/biomass/Pages/biomasshome.aspx

\section{0 Uses of Renewable Energy}

Renewable energy which includes wind, solar, geothermal, hydroelectric and biomass provides substantial benefits for our climate, our health, and our economy. Renewable energy concept remains the same: renewable energy sources, in contrast to fossil fuels, are environmentally friendly, ubiquitous, self-replenishing, infinite, and consequently world-wide as the way of the future. Some of the benefits associated with these energy technologies are as follows;

a. Climate Change Mitigation - change mitigation: Climatic

change due to emissions of greenhouse gases (GHGs) particularly $\mathrm{CO} 2$ becomes an issue when stored solar energy is converted to useable forms of energy(heat, electricity, fuels, chemicals) at a rate far exceeding the rate of formation. For coal, oil and gas, the ratio of time between formation and use is on the order as 1 million to one. This means, the world uses in one year what took natural processes one million years to create. Only biomass among these stored forms has a time ratio that is within a human time frame of years or decades. Renewable energy are available and replenished in time scale no longer than human lifetime.

Human activity is overloading our atmosphere with carbon-dioxide and other global warming emissions which trap heat, steadily drive up the climate's temperature and creates significant impact on our health, our environment and climate. Most renewable energy sources produce little to no global warming emissions. The table below gives a comparison of carbon-dioxide equivalent emitted per Kilowatt-hour [CO2 E/KWH] of some non-renewable energy sources as compared with renewable sources during electricity generation.

Table 2 Carbondioxide Emission by Different Energy Sources

\begin{tabular}{|l|l|}
\hline Energy Source & $\begin{array}{l}\text { Carbondioxide Equivalent } \\
\text { Emitted Per Kilowatt-Hour } \\
\text { (Co2 E/Kwh) }\end{array}$ \\
\hline Natural gas & $0.6-2$ pounds \\
\hline Coal & $1.4-3.6$ pounds \\
\hline Wind & $0.02-0.04$ pounds \\
\hline Solar & $0.007-0.2$ pounds \\
\hline Geothermal & $0.1-0.2$ pounds \\
\hline Hydroelectric & $0.1-0.5$ pounds \\
\hline Biomass & $\begin{array}{l}\text { They have a wide range of } \\
\text { emissions depending on the } \\
\text { resource and how it is harvested. }\end{array}$ \\
\hline
\end{tabular}

Table 6.1 Source: IPCC 2011: Intergovernmental Panel on Climate Change Special Report On Renewable Energy Source and Climate Change Mitigation.

b. Power Generation - the rapidly growing global population is increasingly dependent on efficient and reliable energy solutions. Whether in offices or industry, in medicine or education, in transportation, entertainment or in private households - energy is the basis for growing number of human activities. Energy is the life blood and prerequisite for a good working economy.

Renewable energy can be used to produce off-grid lighting systems. Many people worldwide have no access to public electricity networks and are thus "off-grid". They use lamps that burn fossil fuels, kerosene and millions of tons of CO2 are emitted. These lamps are not only dangerous and hazardous to health but also uneconomical and harmful to the environment. Sustainable lighting solutions for regions without power grids are developed. For example in April 2008, a pilot project was launched on the banks of Lake Victoria in Kenya. A company (OSRAM) built solar-powered energy stations where residents can recharge batteries for energy saving lamps, lights, and other electrical devices like mobile 
phones and radios at low cost) and with low impact on the environment. The new lights and lamps are brighter, safer, healthier, and much more economical than the fossil-fuelled lamps (www.siemens.com).

\section{c. Improved Public Health and Environmental Quality:}

Generating electricity from renewable energy rather than fossil fuels offers significant public health benefits. The air and water pollution emitted by coal and natural gas plants is linked to breathing problems, neurological damage, heart attacks, and cancer. Coal mining and natural gas drilling can pollute sources of drinking water. On the other hand, wind, solar, and hydroelectric systems generate electricity with no associated air pollution emissions. Total air emissions by geothermal and biomass energy systems are generally much lower than those of coal and natural gas fired plants.

d. Jobs and other Economic Benefits - Renewable energy projects in many developing countries have demonstrated that renewable energy can directly contribute to poverty alleviation by providing the energy needed for creating business and employment compared with fossil fuel technology, which are typically mechanized and capital intensive, the renewable energy industry is more labor-intensive. This means that on average, more jobs are created for each unit of electricity generated from renewable resources than from fossil fuels.

Growth in renewable energy industry creates positive economic "ripple" effect. For example, industries in the renewable energy supply chain will benefit, and unrelated local businesses will benefit from increased household and incomes. Local governments collect property and income taxes. These revenues can help support vital public services, especially in rural communities where projects are often located. Owners of land on which wind projects are built also often receive lease payments as well as payment for power line easement and road rights-of-way or they may earn royalties based on the project's annual revenue. Similarly, farmers and rural land owners can generate new sources of supplemental income by producing feedstock for biomass power facilities. Renewable energy projects therefore keep money circulating within the local economy, and in most states renewable electricity production would reduce the need to spend money on importing coal and natural gas from other places.

e. Stabilizes Energy Prices - Renewable energy is providing affordable electricity across the globe and can help stabilize energy prices in the future. The costs of renewable energy technology have declined steadily, and are projected to drop even more as markets mature. For example, the average cost of a solar panel has dropped more than 60\% since 2011(SEIA, 2012). The cost of generating electricity from wind dropped more than 20 percent between 2010 and 2012 and more than 80 percent since 1980 . In areas with strong wind resource like Texas, wind power can compete directly with fossil fuel on cost (ERCOT, 2012).

While renewable facilities require upfront investment to build, once built they operate at very low cost, and for most technologies, the fuel is free. As a result, renewable energy prices are relatively stable over time. In contrast, fossil fuel prices can vary dramatically and are prone to substantial price swings. Using more renewable energy can lower the prices of and demand for natural gas and coal by increasing competition and diversifying our energy supplies. An increased reliance on renewable energy can help protect consumers when fossil fuel price spike.

f. Provision of vast and Inexhaustible Energy Supply - Renewables are present nearly everywhere and available without long transport. This can help countries lacking natural resources gain greater independence from fossil fuels and secure their own climate-friendly energy supply. Strong winds, sunny skies, plant residues, heat from the earth and fastmoving water can each provide a vast and constantly replenished energy resource supply. Hence, renewable energy holds significant potential in mitigating deficiencies in energy supply in developing countries

g. Waste Management - Municipal solid waste can be defined as the post-consumer solid waste generated by residential, commercial, and institutions (schools, hospitals, offices etc.) by (OTA, 1998). Industrial wastes are usually discarded separately from municipal waste. Some of these solid wastes are combustible and are being used as renewable sources of energy. Hence, renewable energy can be used as a means of waste management by elimination of agricultural and household wastes that can be used for biofuel production.

\section{0 Summary and Conclusion}

Renewable energy is derived from non-fossil and non-nuclear sources in ways that can be replenished are sustainable and have no harmful side effect. Renewable energy — wind, solar, geothermal, hydroelectric, and biomass provides substantial benefits for our climate, our health, and our economy:

The abundant non-renewable based energy resources are depleting and contribute huge amount of greenhouse gas emission.

Renewable energy therefore offers solutions to the problems posed by conventional energy sources. The various renewable energy sources, technology and applications are summarized in the table below. 
Table 3: Summary of Renewable Energy and Applications/Uses

\begin{tabular}{|l|l|l|l|l|l|}
\hline RESOURCE & TECHNOLOGY & \multicolumn{3}{l|}{ END-USE APPICATION } & \\
\hline & & Electricity & Industry & Buildings & Transport \\
\hline \multirow{5}{*}{ Solar } & Photovoltaics - Flat Plate & $\checkmark$ & & & \\
\hline & Photovoltaics-Concentrator & $\checkmark$ & & & \\
\hline & $\begin{array}{l}\text { Solar Thermal Parabolic } \\
\text { trough }\end{array}$ & $\checkmark$ & $\checkmark$ & & \\
& Passive Heating & & $\checkmark$ & & \\
\hline & Active Heating & & $\checkmark$ & & \\
\hline & Daylighting & & $\checkmark$ & & \\
\hline \multirow{5}{*}{ Bind } & Horizontal Axis Turbine & $\checkmark$ & & & \\
\hline & Vertical Axis Turbine & $\checkmark$ & & & \\
\hline \multirow{5}{*}{ Geothermass } & Direct Combustion & $\checkmark$ & $\checkmark$ & $\checkmark$ & \\
\hline & Gasification/Pyrolysis & $\checkmark$ & $\checkmark$ & & $\checkmark$ \\
\hline & Anaerobic Digestion & $\checkmark$ & $\checkmark$ & $\checkmark$ & \\
\hline & Fermentation & & & & $\checkmark$ \\
\hline & Dry Steam & $\checkmark$ & & & \\
\hline & Flash Steam & $\checkmark$ & & & \\
\hline & Binary Cycle & $\checkmark$ & & & \\
\hline & Heat Pump & & & $\checkmark$ & \\
\hline & Direct Use & & $\checkmark$ & $\checkmark$ & \\
\hline Hydropower & Large scale hydropower & & & & \\
\hline & Micro-hydro power & $\checkmark$ & & & \\
& & & & & \\
\hline
\end{tabular}

Renewable energy has come a long way in recent years, and all trends are pointing to a further decrease in costs, increase in popularity and efficiency improvements. But, as with all technology, renewable energy has some room for improvement.

The goal of limiting the concentrations of greenhouse gas emission in the atmosphere while satisfying a continued growth in energy demand presents a huge but vital challenge for the world and Nigeria in particular. The scientific community has been seeking solutions to these challenges - often by looking to nature for solutions. Policies have to be strengthened to reduce the dependence on fossil fuels and adopt more of renewable sources in the energy mix which will offer significant environmental, health and economic advantages.

\section{Refernces}

[1].Adelekan, B.A.,and Adelekan, I.O., (2004). Health implications of household energy use in selected Nigerian towns. Nigerian Journal of Renewable Energy, 12(1\&2), 138 - 146.

[2].Brown, A., Muller S., and Dobrotkova Z., (2011). Renewable Energy Markets and Prospects by Technology, International Energy Agency (IEA/OECD, Paris.

[3].Carpentieri, A. E., Larson, E. D., and Woods, J., (1993). "Future Biomass-Based.

[4].Eco-friendly Off Grid lighting for developing ... Siemens www.siemens.com/press/en/.../2008/.../0803_projektlaunc hkenya.htm Mar 31, 2008

[5].Electricity Reliability Council of Texas (ERCOT). 2012. Long Term System Assessment for the ERCOT region.

[6].Electricity Supply in Northeast Brazil", Biomass and Bioenergy 4:149-174

[7].Energy Commission of Nigeria (2005). Renewable Energy Master Plan.

[8].Gupta, J.B.,( 2000). “A Course in Power System” Sanjeev, Kumar Katari and Sons, Nai Sarak, Delhi.

[9].Hall, D.O., (1993). "Biomas For Energy: Supply Prospect”, in Johansson.

[10]. IPCC Special Report on Renewable Energy Source and Climatic Change Mitigation, 2011. Prepared by Working Group III of the Intergovernmental Panel on Climatic Change.

[11]. Intergovernmental Panel on Climate Change (IPCC) (2011). Special Report on Renewable Energy Sources and Climate Change Mitigation, Working Group III- Mitigation of Climatic Change, IPCC. Karekezi A., and Ranja S., (1997). Renewable Energy Technologies in Africa, Zed Books Limited with Africa Energy Policy Research Network (AFREPREN) and Stockholm Environment Institute (SEI). Marshall, A.T., (2007). Bioenergy from Waste: A Growing Source of Power Waste Management. World Magazine, April 34-37. www.wastemanagement worldmagazine/.

[12]. Moreira, J.R., and Poole A.D.,(1993): "Hydropower and Its Constraints," in Johansson.

[13]. Nigeria Journal of Solar Energy. ISSN: 0794-9537, Volume 23, 2012. Published by Solar Energy Society of Nigeria. www.sesn-ng.org

[14]. Russell, M., Jantzen, D., and Shen, Z., (1992). Electricity From Biomass: Two Potential Chinese

Projects, Energy, Environment and Resource Center, University of Tennessee, Knoxville. Solar Market Insight Report (SEIA). 2012 Sorenson, B., (1979). Renewable Energy, London: Academic Press.

[15]. Ibidapo-Obe O., and Ajibola O. E., (2011). Towards a Renewable Energy Development for Rural Power Sufficiency. International Conference on Innovations in Engineering and Technology (IET), August $8^{\text {th }}-10^{\text {th }} 2011$

[16]. OTA. 1989: Facing America's Trash- What Next for Municipal Solid Waste? OTA-O-424, U.S. Congress. Office of Technology Assessment, Washington, D.C: U.S Government Printing Office

[17]. Perlack, R.D., Ranney, J.W., and Russell, M., (1991). Biomass Energy Development in Yunnan Province, China. Oak Ridge National Laboratory, ORNL/TM-11791, Oak Ridge Tennessee. 
[18]. Tamilade, S., (2008). Status of Renewable Energy Policy and Implementation in Nigeria. Institute of Science and Society, University of Nottingham, United Kingdom.

[19]. Twidell, Weir (1986). Renewable Energy Resources, London: Academic Press Top 10 Technology Advances in Renewable Energy (2012).gogreencyclopedia.blogspot.com/.../top-10technology-advances-in-rene.

[20]. Wiser, R., and Mark, B., (2012). Wind Technologies Market Report. US Department of Energy 